Neurological Research is an international journal for reporting both basic and clinical research in the fields of neurosurgery, neurology and neurosciences. It provides a medium for those who recognize the wider implications of their work and who wish to be informed of the relevant experience of others in related and more distant fields.

Published bimonthly by Forefront Publishing, Celtic House, 33 John's Mews, London WC1N 2QL, UK

Annual Subscriptions: Volume 15, 1993 (6 issues)

Institution: USA and Canada rate US $\$ 415.00$ plus $\$ 35.00$ postage and handling; Rest of world rate: UK£245.00 plus $£ 20.00$ postage and handling. Personal rate including postage: USA and Canada US\$85.00; Rest of world UK $£ 55.00$. Prices are for accelerated surface mail (air-speeded to USA and Canada). Airmail prices available on request.

Subscription orders for USA and Canada should be sent to PO Box 1061, Framingham MA 01701 USA. Orders for the rest of the world should be sent to Celtic House, 33 John's Mews, London WC1N 2QL, UK

US mailing agents: Expediters of the Printed Word Ltd. Second class postage paid at Rahway, NJ, US. Postmaster: send address corrections to Neurological Research, c/o Expediters of the Printed Word Ltd., 2323 Randolph Avenue, Avenel, NJ 07001, USA.

Back issues prior to 1990 are available from Wm. Dawson \& Sons Ltd., Cannon House Folkestone, Kent CT19 5EE, UK. Tel 0303 850101 . For volume 12 issues onwards, apply to Neurological Research, Celtic House, 33 John's Mews, London WC1N 2QL, UK

Microfilm copies of this journal are available from University Microfilms, 300, N. Zeeb Road, Ann Arbor, MI 48106, USA.

Copyright: All rights reserved. No part of this publication may be reproduced, stored in a retrieval system or transmitted, in any form or by any means (electronic, mechanical, photocopying, recording, or otherwise) without the written permission of the publisher. Readers who require copies of the papers published in this journal may either purchase reprints or obtain permission to copy from the publisher at the following address, Forefront Publishing, Celtic House, 33 John's Mews, London WC1N 2QL, UK. For readers in the USA permission to copy is given on the condition that the copier pay the stated per copy fee through the Copyright Clearance Center, Inc., 21 Congress Street, Salem, MA 01970 for copying beyond that permitted by Sections 107 and 108 of the U.S. Copyright Law. The current fee is $\$ 6.00$ per article.

\section{ISSN 0161-6412}

(C) 1993 Forefront Publishing Group NRESDZ 15(4) (217-288) (1993)

Typeset by P\& R Typesetters Ltd, Salisbury, Wilts, UK. Printed in Great Britain.

This journal is included in Index Medicus; Current Contents/Life Sciences; BIOSIS: Excerpta Medica; Current Awareness in Neurosciences; Current Awareness in Biological Sciences; Reference Update; Research Alert; SCISEARCH; Neuroscience Citation Index

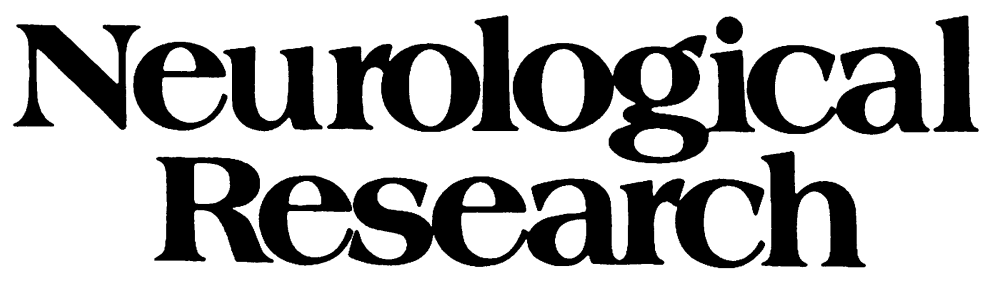

A journal of progress in Neurosurgery, Neurology and Neurosciences

\section{Volume 15 Number 4 August 1993}

\section{Contents}

Review

Calcium antagonists for the treatment of vasospasm following subarachnoid haemorrhage

\section{Papers}

Chronic electrical stimulation of the facial nerve causes signs of facial nucleus hyperactivity

Shinjiro Saito and Aage R. Møller

Middle cerebral artery occlusion increases cerebral capillary permeability

M. Anwar, O. Costa, A.K. Sinha and H.R. Weiss

Determination of regional cerebral oxygen consumption in the human: ${ }^{17} \mathrm{O}$ Natural abundance cerebral Magnetic Resonance Imaging and spectroscopy in a whole body system

Daniel Fiat, Janez Dolinsek, Janus Hankiewicz, Manuel Dujovny and lames Ausman

Impairment of hippocampal long-term potentiation following transient cerebral ischaemia in rat: Effects of bifemelane, a potent inhibitor of ischaemia-induced acetylcholine release

Shuhei Miyazaki, Yoichi Katayama, Makoto Furuichi, Kosaku Kinoshita, Tatsuro Kawamata and Takashi Tsubokawa

Cardiac arrest-induced complete cerebral ischaemia in the rat: Dynamics of postischaemic in vivo calcium uptake and protein synthesis

Günter Mies, Kensuke Kawai, Nobuhito Saito, Goro Nagashima, Thaddeus S, Nowak Ir., Christl A. Ruetzler and Igor Klatzo

Microcirculation in experimental brain oedema assessed by laser-Doppler flowmetry

Suguru Inao, Hiroji Kuchiwaki and Kenichiro Sugita

Long-term survival of autologous adrenal medulla grafts in the great omentum of the rat

Aminadav Mendelowitsch, Tiang-Ming Zhang, Csaba Vereczkey, Manfred Gratzl and Otmar Gratzl

Surgical approaches to the anterior communicating artery aneurysm and their results

Ahmed Diraz, Shigeaki Kobayashi, Toshihide Toriyama, Michihiko Ohsawa, Masanobu Hokama and Kazuo Kitazama

Profiles of extracellular amino acid changes in focal cerebral ischaemia: Effects of mild hypothermia

Eng H. Lo, Gary K. Steinberg, Nariman Panahian, Nigel T. Maidment and Robert Newcomb

Conference Calendar
Kazuhiro Hongo and Shigeaki Kobayashi 


\title{
Long-term survival of autologous adrenal medulla grafts in the great omentum of the rat
}

\author{
Aminadav Mendelowitsch*, Tiang-Ming Zhang $\dagger$, Csaba Vereczkey $\ddagger$, \\ Manfred Gratzl§ and Otmar Gratz**
}

\begin{abstract}
*Department of Neurosurgery, University Hospital of Basle, Switzerland; †Beijing Neurosurgical Institute, China; $\ddagger$ Department of Anatomy, A. Szent Cyörgyi Medical University, Szegerd, Hungary, and §Department of Anatomy and Cell Biology, University of Ulm, Germany

The omentum, a rich source for trophic and angiogenic factors, was explored as a potential intermediate transplant site to facilitate long-term survival of chromaffin tissue. Autologous rat adrenal medullas were grafted into omental pockets. All grafts became densely vascularized. The grafted chromaffin tissue exhibited strong immunoreactivities for tyrosine hydroxylase, synaptophysin and chromogranin A throughout the observation period of 16 weeks. The expression of these markers implies that grafted chromaffin cells retained the key enzyme for catecholamine biosynthesis and the organelles required for catecholamine secretion. Moreover, intermediate transplant of chromaffin tissue to the omentum could provide a favourable conditioning microenvironment thus augmenting the potential for survival of functional chromaffin tissue. [Neurol Res 1993; 15: 269-272]
\end{abstract}

Keywords: Great omentum; adrenal medulla; autotransplantation; Parkinson's disease, immunocytochemistry

\section{INTRODUCTION}

Despite promising preliminary reports ${ }^{1,2}$, clinical and experimental investigations for direct transplantation of autologous adrenal medulla chromaffin tissue into the brain have yielded only short-term amelioration of catecholamine deficiencies ${ }^{3,4}$. Lack of trophic factors and poor or delayed vascularization may have contributed to the rapid cell death of the chromaffin cells.

There are several reasons to believe that the great omentum could serve as an ideal intermediate conditioning site for adrenal medullary grafts. It is a densely vascularized organ and contains a variety of angiogenic and neurotrophic factors ${ }^{5,6}$.

Here we report on the long-term survival of adrenal medullary cells when transplanted into the great omentum of the rat. We examined the vascularization of the transplanted tissue and the function of the chromaffin cells as indicated by the expression of tyrosin hydroxylase, synaptophysin and chromogranin A.

\section{METHODS}

Twenty-seven adult wistar rats $(250 \mathrm{~g}$ body weight at the time of implantation) served as both tissue donors and recipients. The left adrenal was removed under anaesthesia $(5 \%$ chloral hydrate, $1 \mathrm{ml}$ intraperitoneal; $0.5 \mathrm{ml}$ Atropine, $0.1 \mathrm{mg} \mathrm{ml}^{-1}$ subcutaneously) and placed in lactated Ringers Solution. The resected cortex of the adrenal gland was microdissected from the medulla and the medulla cut into approximately $1 \mathrm{~mm}$ pieces for subsequent transplantation. A small pocket was made between the two membranes of the great

Correspondence and reprint requests to: Dr Aminadav Mendelowitsch, Department of Neurosurgery, University Hospital Basle, 4031 Basle, Switzerland. Accepted for publication March 1993. omentum near the gastroepiploic artery or its branches. After insertion of medullary tissue pieces, the pocket was closed with two sutures (10-0) and marked with a mini Hemo-Clip.

The autografts were examined one day, 2, 4, 6, 8, $10,12,14$ and 16 weeks following transplantation. There were 3 rats in each group except the 8 week group which consisted of 2 rats. The excised transplants were immersed in Bouin's fixative for $6 \mathrm{~h}$, subsequently dehydrated with ethanol, embedded in paraffin and sectioned at 4-6 micrometers.

\section{Immunocytochemistry}

The avidin-biotin-peroxidase $(A B C)$ technique ${ }^{7}$ was performed on deparaffinized paraffin sections. Endogenous peroxidase activity was blocked with $0.3 \% \mathrm{H}_{2} \mathrm{O}_{2}$ and $10 \%$ methanol in phosphate-buffered saline (PBS). Sections were made permeable in Triton- $X 100(0.5 \%$ in PBS, pH 7.4) for $5 \mathrm{~min}$. Subsequently some sections were incubated $(20 \mathrm{~min}$ ) with $10 \%$ normal goat serum prior to incubation with synaptophysin (SYN) - or chromogranin A (CCA) - antiserum. Other sections were incubated (20 min) with $10 \%$ normal horse serum prior to incubation with the tyrosine hydroxylase (TH)antiserum. The sections were then incubated overnight with polyclonal rabbit serum against rat SYN (antibody C95, dilution 1:2000, kindly provided by $\operatorname{Dr} R$. Jahn, New Haven, $C T$, USA), a rabbit antiserum directed against the $C$-terminal 16 amino acid sequence of bovine CCA (dilution 1:1000, kindly provided by D.T. O'Connor, San Diego, CA, USA) or with anti-TH (monoclonal, dilution 1:1000, Boehringer Mannheim, Germany).

For the detection of SYN and CGA, biotinylated anti-rabbit IgC (diluted 1:500, Vector, Burlingame, CA, USA) and ABC-complex (diluted 1:200, Vector, Burlingame, CA, USA) were used in the second and third steps of the immunostaining. Biotinylated anti-mouse IgG (diluted 
1:500, Vector, Burlingame, CA, USA) was used as second antibody during immunostaining for TH. The immunoreaction was visualized with a freshly prepared solution of $0.05 \% \quad 3,3^{\prime}$ diaminobenzidine-tetrahydrochloride (Aldrich, Milwaukee, USA) and $0.01 \% \mathrm{H}_{2} \mathrm{O}_{2}$ in $0.1 \mathrm{M}$ Tris- $\mathrm{HCl}$ buffer ( $\mathrm{pH} 7.6$ ) for up to $10 \mathrm{~min}$. In control sections the primary antibody was replaced by normal serum. Sections were photographed using a ZeissPhotomicroscope. Other sections were stained with haematoxylin and eosin.

\section{RESULTS}

\section{General}

All rats appeared healthy throughout the observation period except for one rat in the 8 week group which developed an abdominal wall herniation and was excluded. Macroscopic observations of the transplants in situ revealed neovascularisation in the graft sites beginning two weeks after transplantation (Figure 1). At the light microscopic level none of the transplants showed any signs of haemorrhage or chromaffin tissue degeneration. In the conventional haematoxylin and eosin stains we observed abundant capillary networks around the grafts. No obvious evidence of inflammatory reaction was noted.

\section{Immunocytochemistry}

As shown in Figures 2 and 3 chromaffin cells grafted in the omental pocket exhibited strong immunoreaction against characteristic antigens of chromaffin cells. This holds a) for tyrosine hydroxylase, which is the main regulatory enzyme in catecholamine biosynthesis; ${ }^{8}$ b) for the intracellular membrane antigen synaptophysin ${ }^{9-11}$ and c) for chromogranin $A^{12,13}$, which is stored and released together with the catecholamines from adrenal medullary chromaffin cells. Interestingly, subjective observations of control (i.e., one day after transplantation) immunoreactivities were not markedly different from immunoreactivities 2 or 16 weeks after transplantation. The grafted chromaffin cells retained their endocrine phenotype and did not develop processes.

\section{DISCUSSION}

Since adrenal medullary cells synthesize dopamine and have the potential for growing neuronal-like processes $^{14-16}$, they have been suggested as a possible replacement for the dopamine neurons which are lost in Parkinson-like disease. However, the survival of grafted chromaffin cells in the brain is limited. Studies in several species including humans showed disappointing results concerning viability of chromaffin cells ${ }^{17-23}$. Only few adrenal chromaffin cells survive neural implantation unless supplemented with exogenous $\mathrm{NCF}^{23}$. Another strategy to improve survival involves cografts of chromaffin cells with other cells producing trophic factors ${ }^{24}$. Surprisingly even tissue grafts containing no chromaffin cells ameliorated experimental parkinsonism ${ }^{24-27}$

In our approach to enhance the survival of adrenal medullary cells we explored the omentum as an intermediate site for the adrenal medullary grafts. The omentum is a multipotent organ with angiogenic as well as neurotrophic factors ${ }^{5,28-32}$ which could provide a vascularized and conditioning microenvironment for the chromaffin cells. Lack of growth factors might be one of the reasons for rapid degeneration and death of chromaffin cells transplanted into the brain. It is well known that the survival of chromaffin cells depends on such factors and in addition themselves produce growth factors ${ }^{33}$. Furthermore - and relevant to transplantation - chromaffin cells are able to grow processes in response to NGF and bFGF ${ }^{14-16}$. Also fibre outgrowth in the host tissue suggests that the adrenal medullary grafts provide important trophic factors for striatal dopaminergic neurons ${ }^{17}$. The great omentum

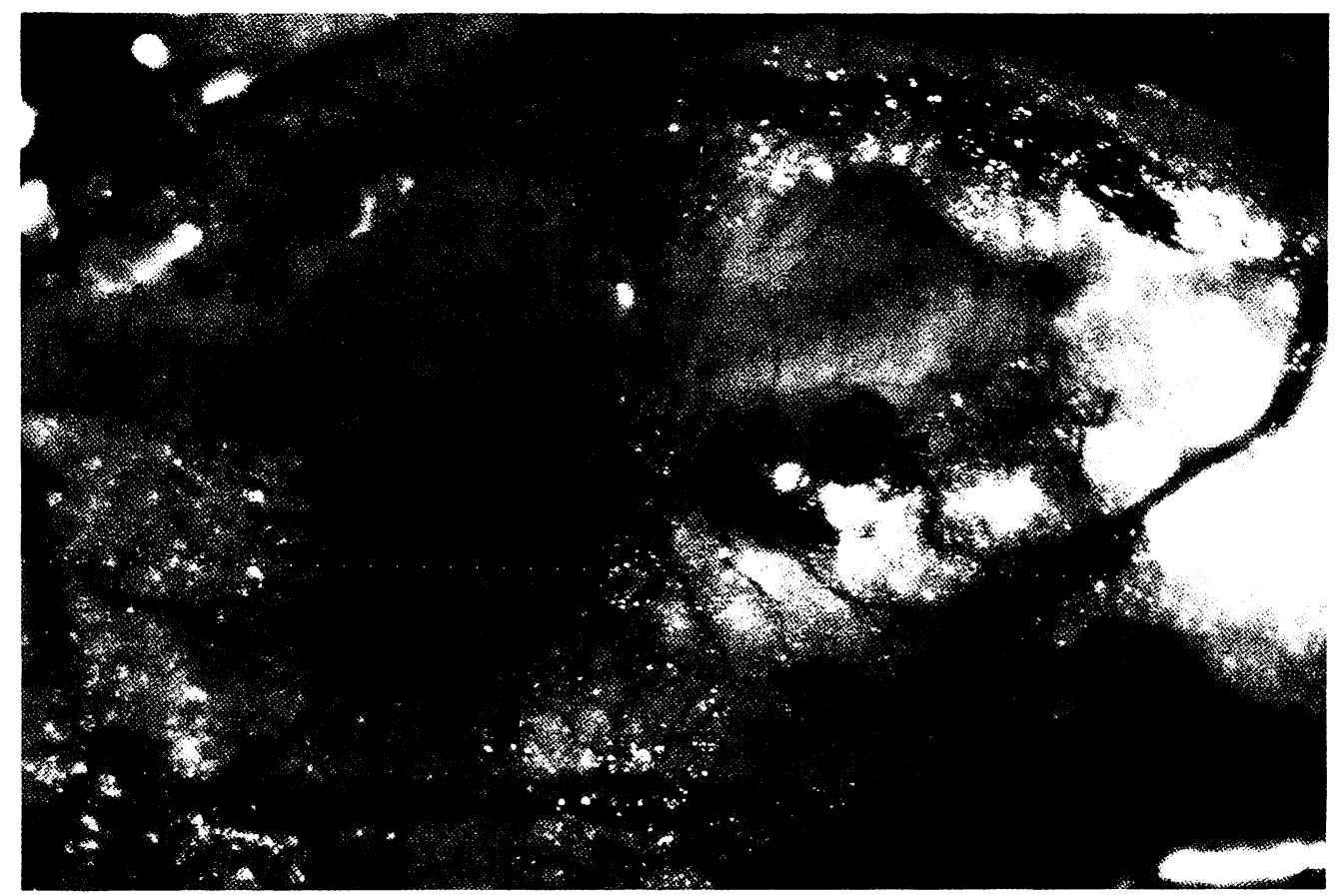

Figure 1: A low magnification view of an adrenal medulla autograft within the omentum, 4 weeks after graft implantation. Neovascularization $(D)$ builds a network around the transplant $(\rightarrow) \times 10$ 

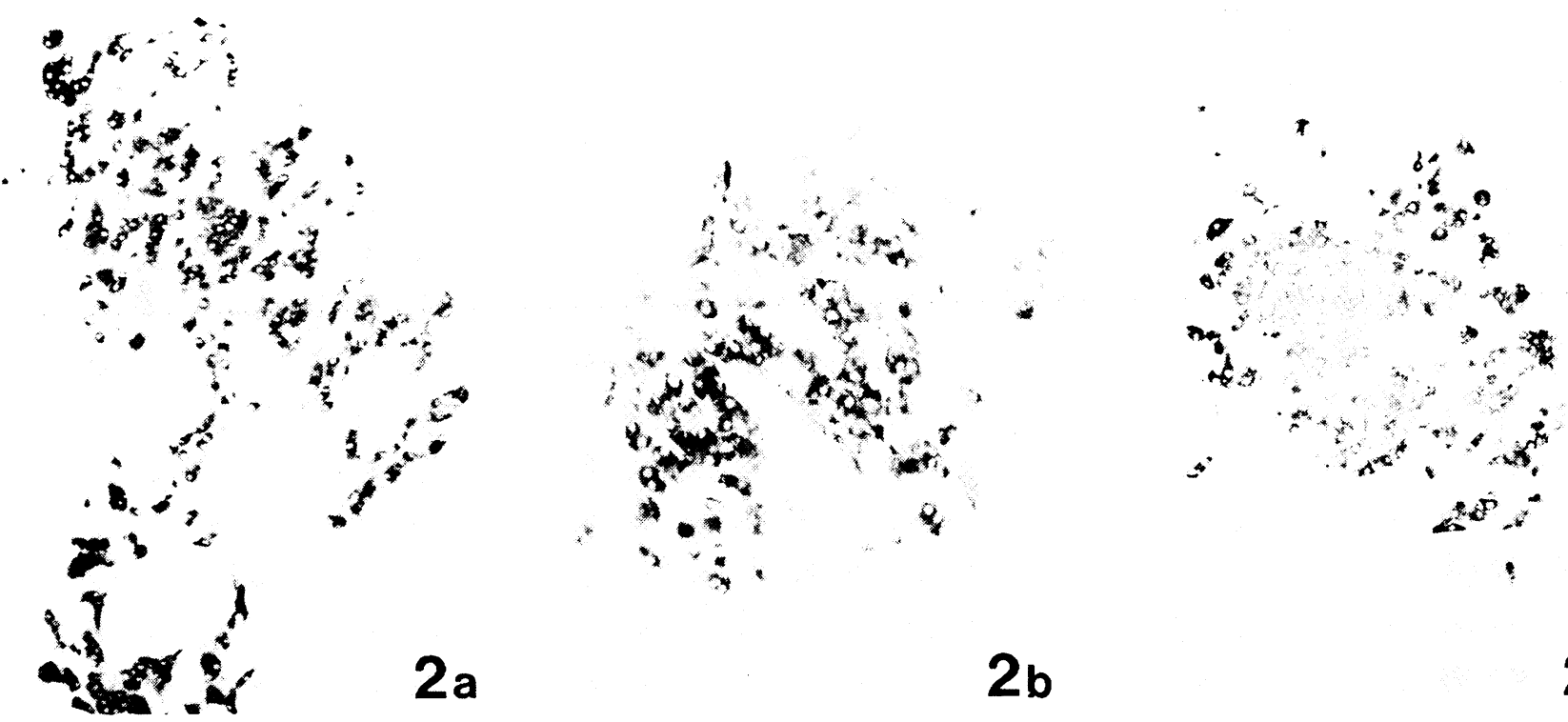

$2 b$

Figure 2: (a) Immunocytochemical evidence of graft survival in the great omentum 2 weeks after transplantation. (b) The graft shows pronounced $\mathrm{TH}$-immunoreactivity $\times 20$. (c) Surviving chromaffin cells demonstrate strong chromogranin $\mathrm{A}$ immunoreactivity $\times 20$ and synaptophysin expression $\times 20$
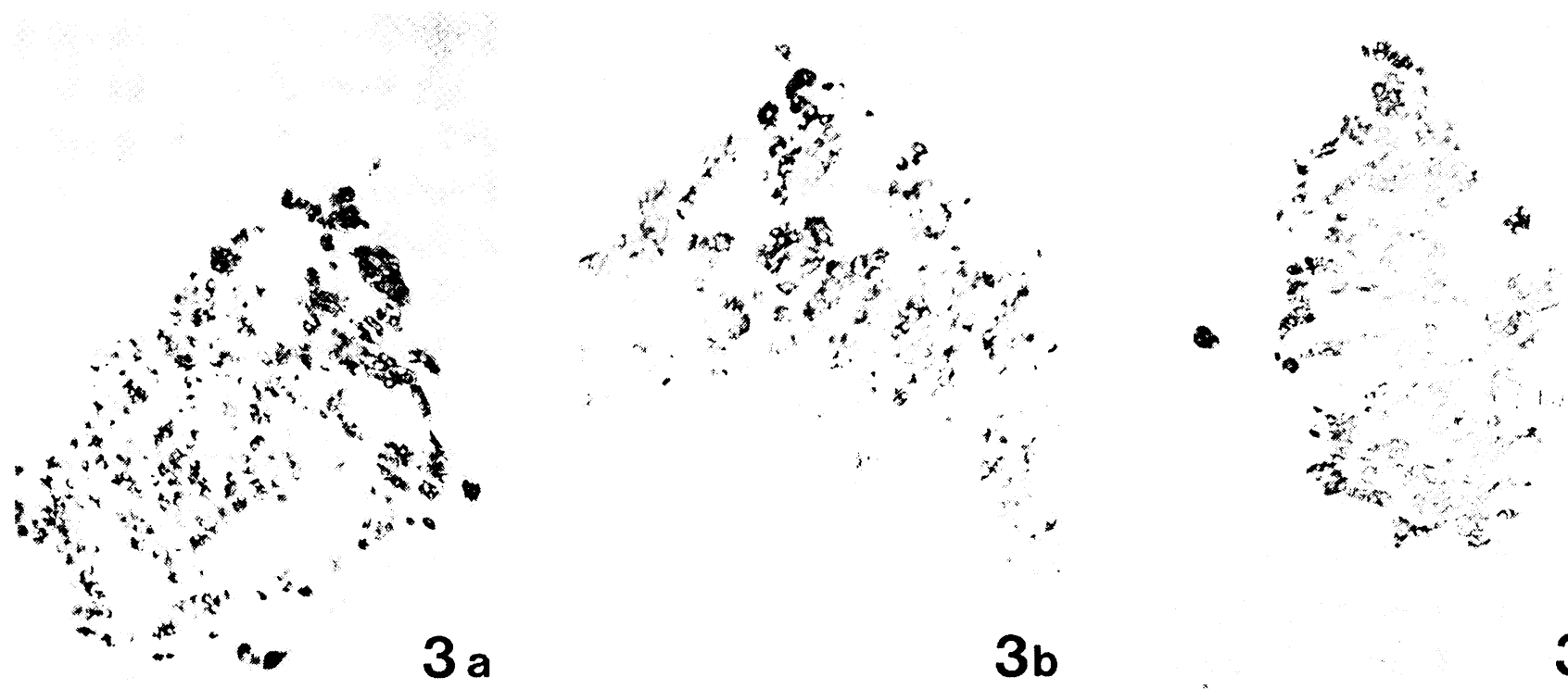

Figure 3: Immunocytochemical evidence of graft survival in the omentum 16 weeks after transplantation, a strong immunoreaction in the grafted adrenal medulla is still evident. (a) Tyrosine hydroxylase $\times 20$. (b) Chromogranin $A \times 20$. (c) Synaptophysin $\times 20$

is a highly vascularized organ producing a variety of angiogenic and trophic factors which promote survival of transplanted chromaffin cells. Acidic FGF and basic FGF have been purified from bovine omentum ${ }^{32}$. Basic FCF has also been isolated from human omentum and high and low affinity receptors for basic FCF have been demonstrated in human omental microvascular endothelial cells ${ }^{5}$.

Our results demonstrate long-term survival of autologous adrenal medulla grafts in the rat omentum (16 weeks). It is reasonable to assume that surviving chromaffin cells are functionally intact because of their strong tyrosine hydroxylase, synaptophysin- and chromogranin A immunoreactivities.

In conclusion, our results indicate that adrenal medulla grafts in the rat omentum have a long-term survival potential. In the next step we will examine if this tissue survives in its subsequent CNS transplantation and is immunocytochemically viable.

\section{ACKNOWLEDGEMENTS}

We thank H. Traurig (Dept. of Anatomy and Neurobiology, University of Kentucky) for his help during the preparation of this manuscript and $M$. Bergmann for his immunocytochemical expertise in the early stages of this work. The expert technical assistance of I. Urban is greatfully acknowledged. This work was supported by the Research Funds of the Department of Surgery, University of Basle, Switzerland. 


\section{REFERENCES}

1 Madrazo I, Drucker-Colin R, Torres C, et al. Long-term (more than one year) evolution of patients with adrenal medullary autografts to the caudate nucleus for the treatment of Parkinson's disease. Proceedings of the XVI CINP Congress. Munich, 15-19 August, 1988

2 Madrazo I, Drucker-Colin R, Diaz V, et al. Open microsurgical autografts of adrenal medulla to the right caudate nucleus in two patients with intractable Parkinson's Disease. N Eng / Med 1987; 316: 831-834

3 Backlund EO, Granberg PO, Hamberger B, et al. Transplantation of adrenal medullary tissue to striatum in parkinsonism. I Neurosurg 1985; 60: 169-173

4 Lindvall O, Backlund EO, Farde L, et al. Transplantation in Parkinson's disease: Two cases of adrenal medullary grafts to the Putamen. Ann Neurol 1987; 22: 457-468

5 Bikfalvi A, Alterio J, Inyang AL, et al. Basic fibroblast growth factor expression in human omental microvascular endothelial cells and the effect of phorbol ester. J. Cell Physiol 1990; 144: 151-158

6 Goldsmith HS, Griffith AL, Kupferman A, et al. Lipid angiogenic factor from omentum. JAMA 1984; 252: 2034-2036

7 Hsu SM, Raine L, Fanger $H$. Use of avidin-biotin-peroxidase complex $(A B C)$ in immunoperoxidase technique: $A$ comparison between $A B C$ and unlabled antibody (PAP) procedures. I Histochem Cytochem 1981; 29: 577-580

8 Zigmond RE, Schwarzschild MA, Rittenhouse AR. Acute regulation of tyrosine hydroxylase by nerve activity and by transmitters via phosphorilation. Ann Rev Neurosci 1989; 12 415-461

9 Jahn R, De Camilli P. Membrane proteins of synaptic vesicles: Markers for neurons and endocrine cells; Tools for the study of neurosecretion. In: Langley K, Gratzl $M$, eds. Markers for Neural and Endocrine Cells. Molecular and Cell Biology, Diagnostic Applications. Weinheim, Germany: VCH-VerlagGesellschaft, 1991: pp. 25-92

10 Jahn R, Schiebler W, Ouimet C, et al. A 38,000 dalton membrane protein (p38) present in synaptic vesicles. Proc Natl Acad Sci USA 1985; 82: 41374141

11 Thomas L, Hartung K, Langosch D, et al. Identification of synaptophysin as a hexameric channel protein of the synaptic vesicle membrane. Science 1988; 242: 1050-1053

12 Huttner WB, Gerdes HM, Rosa P. Chromogranin/Secretogranin - widespread constituents of the secretory granule matrix in endocrine cells and neurons. In: Langley $K$, Gratzl $M$, eds. Markers for Neural and Endocrine Cells. Molecular and Cell Biology, Diagnostic Applications. Weinheim, Germany: $\mathrm{VCH}$ Verlag-Gesellschaft, 1991: pp. 93-131

13 Huttner WB, Gerdes HM, Rosa P. The granin (chromogranin/ secretogranin) family. TIBS 1991; 16: 27-30

14 Claude $\mathrm{P}$, Prada IM, Gordon KA, et al. Acidic fibroblast growth-factor stimulates adrenal chromaffin cells to proliferate and to extend neurites, but is not a long-term survival factor. Neuron 1988; 1: 783-790

15 Stemple DL, Mahanthappa NK, Anderson DJ. Basic FGF induces neuronal differentiation, cell division, and NGF dependence in chromaffin cells - A sequence of events in sympathetic development. Neuron 1988; 1: 517-525

16 Unsicker K, Kirsch B, Otten U, et al. Nerve growth factor-induced fiber outgrowth from isolated rat adrenal chromaffin cells: impairment by glucocorticoids. Proc Natl Acad Sci USA 1978; 75: 3498-3502

17 Bohn MC, Marciano F, Cupit L, et al. Recovery of dopaminergic fibres in striatum of the 1-methyl-4-phenyl-1,2,3,6 tetrahydropyridine-treated mouse is enhanced by grafts of adrenal medulla. In: Gash DM, Sladek JR, eds. Progress in Brain Research, Vol. 78. The Netherlands: Elsevier, 1988: pp. 535-542

18 Bohn MC, Cupit L, Marciano F, et al. Adrenal medulla grafts enhance recovery of striatal dopaminergic fibres. Science 1987; 237: 913-915

19 Fiandaca MS, Kordower $\mathrm{JH}$, Hansen $\mathrm{JT}$, et al. Adrenal medullary autografts into the basal ganglia of Cebus monkeys: Injuryinduced regeneration. Exp Neurol 1988; 107: 76-91

20 Hansen JT, Fiandaca MS, Kordower JH, et al. Striatal adrenal medulla/sural nerve cografts in hemiparkinsonian monkeys. In: Dunnett SB, Richards SJ, eds. Progress in Brain Research, Vol. 82. The Netherlands: Elsevier, 1990: pp. 573-580

21 Morihisa JM, Nakamura RK, Freed WJ, et al. Adrenal medulla grafts survive and exhibit catecholamine-specific fluorescence in the primate brain. Exp Neurol 1984; 84: 643-653

22 Peterson DI, Lynne M, Small CS. Autopsy findings in a patient who had an adrenal-to-brain transplant for Parkinson's disease. Neurology 1989; 39: 235-238

23 Strömberg J, Herrera-Marschitz M, Ungerstedt U, et al. Chronic implants of chromaffin tissue into the dopamine-denervated striatum. Effects of NCF on graft survival, fiber growth and rotational behavior. Exp Brain Res 1985; 60: 335-349

24 Bing G, Notter MFD, Hansen JT, et al. Cografts of adrenal medulla with $\mathrm{C} 6$ glioma cells in rat with 6-OHDA-induced lesions. Neuroscience 1990; 34: 687-697

25 Bankiewicz KS, Plunkett R, Jacobowitz DM, et al. Fetal nondopaminergic neural implants in parkinsonian primates. / Neurosurg 1991; 74: 97-104

26 Kordover JH, Fiandaca MS, Notter MFD, et al. NGF-like trophic support for grafted rhesus adrenal chromaffin cells. I Neurosurg 1990; 73: 418-428

27 Pezzoli G, Faku S, Dwork A, et al. Non chromaffin tissue plus nerve growth factor reduces experimental parkinsonism in aged rats. Brain Res 1988; 459: 398-403

28 Cartier R, Brunette J, Hashimoto K, et al. Angiogenic factors: A possible mechanism for neovascularization produced by omental pedicles. I Thorac Cardiovasc Surg 1990; 99: 264-268

29 Goldsmith HS, Griffith AL, Kupferman A, et al. Increased vascular perfusion after administration of an omental lipid fraction. Surg Cynecol Obst 1986; 162: 579--583

30 Imaizumi T, Hashi K, Kanoh $\mathrm{H}$. Non heparin binding endothelial cell growth factor from bovine omentum. Exp Cell Res 1990; 187: $292-298$

31 Nottebaert $M$. Lane J-M, Juhn $A$, et al. Omental angiogenic lipid fraction and bone repair. An experimental study in the rat. / Orthop Res 1989; 7: 157-169

32 Ohtaki T, Wakamatsu K, Mori M, et al. Purification of acidic fibroblast growth factor from bovine omentum. Biochem Biophys Res Commun 1989; 161: 169-175

33 Grothe C, Unsicker K. Immunocytochemical localisation of basic fibroblast growth factor in bovine adrenal gland, ovary and pituitary. / Histochem 1989; 37: 1877-1883 